\title{
PENGARUH BIMBINGAN BELAJAR TERHADAP KEJENUHAN DALAM BELAJAR PADA SISWA KELAS XI DI SMAN I GERUNG KABUPATEN LOMBOK BARAT
}

\section{Nihayah*}

\begin{abstract}
Abstrak: Bimbingan belajar adalah suatu bantuan dari pembimbing kepada individu (siswa) dalam hal menemukan cara belajar yang tepat, dalam memilih program studi yang sesuai dan dalam mengatasi kesukaran-kesukaran yang timbul berkaitan dengan tuntutan-tuntutan belajar di institusi pendidikan.Penelitian ini bertujuan untuk mengemukakan pengaruh layanan bimbingan belajar terhadap kejenuhan dalam belajar pada siswa kelas XI di SMAN 1 Gerung Kabupaten Lombok Barat. Penentuan subyek menggunakan metode Purposive Sampling. Yang menjadi sampel dalam penelitian ini adalah siswa kelas XI IPS. Metode pengumpulan data yang digunakan dalam penelitian ini berupa angket sebagai metode pokok sedangkan, wawancara, dokumentasi dan observasi sebagai metode pelengkap. Analisis data menggunakan rumus t-test. Berdasarkan hasil analisis data dengan taraf signifikan $5 \%(0,05)$ dengan $\mathrm{N}=15$ maka diperoleh hasil penelitian yaitu nilai t-bitung lebih besar dari nilai t-tabel ( $t$ hitung8,166>t-tabel 2,145) kenyataan ini menunjukkan bahwa nilai $t$ bitung yang diperoleh adalah signifikan, maka dapat disimpulkan bahwa hipotesis alternatif $(\mathrm{Ha})$ diterima.
\end{abstract}

Kata Kunci : bimbingan belajar, dan kejenuhan dalam belajar.

B erbagai masalah yang dihadapi untuk mewujudkan pendidikan dan pengembangan diri yang optimal. Yaitu salah satunya timbul dari dalam diri pesertadidik sehingga memungkinkan akan berpengaruh negative pada hasil belajar yang

Mahasiswa Pascasarjana UIN Sunan Kalijaga Yogyakarta, Jurusan Interdisciplinary Islamic Studies, Konsentrasi Bimbingan Dan Konseling Islam. 2017-2018. Email: nihayah845@gmail.com 
akan dicapainya.Timbulnya kendala dalam diri siswa untuk mencapai pengembangan diri yang optimal, mandiri dan bertanggung jawab berkaitan dengan kejenuhan mereka pada saat proses belajar berlangsung.

Kejenuhan dalam belajar yang dialami siswa yang belajar pada rentang waktu tertentu, akan berakibat terhadap hasil belajarnya, dengan menciptakan suasana belajar yang baik dan nyaman, maka siswa akan mencapai prestasi belajar yang optimal. Jika peserta didik mendapatkan kenyamanan dalam proses belajar maka peserta didik dapat bertanggung jawab terhadap dirinya sendiri, dan mampu mencapai segala sesuatu yang diinginkannya.

Keberhasilan untuk menghilangkan kejenuhan dalam belajar pada pesertadidik, tidak terlepas dari usaha atau strategi sekolah dalam memaksimalkan peran guru BK. Hal ini terkait bagaimana guru BK menerapkan teori-teori bimbingan dan konseling dalam memecahkan masalah dan menciptakan suasana belajar yang baik bagi siswa. Berbagai layanan telah dikembangkan untuk membantu siswa untuk mencapai perkembangan diri yang optimal. Salah satu layanan yang diterapkan untuk menciptakan suasana belajar yang nyaman dan menghilangkan kejenuhan dalam belajar pada saat belajar yaitu layanan Bimbingan Belajar.

Layanan bimbingan belajar guna membantu siswa untuk memecahkan masalah yang dihadapinya, baik masalah belajar maupun sosial agar individu dapat berkembang optimal sebagaimana yang diharapkan.

Pemberian layanan bimbingan belajar untuk menghilangkan kejenuhan dalam belajar siswa, diharapkan siswa memiliki kebiasaan belajar yang baik untuk menguasai pengetahuan dan keterampilan serta menyiapkan melanjutkan pendidikan ke jenjang yang lebih tinggi. Serta bertanggung jawab terhadap dirinya sendiri dan lingkungan sekitarnya.

Berdasarkan hasil observasi lapangan di SMAN 1 Gerung Kabupaten Lombok Barat, ada sebagian siswa yang mengalami kejenuhan dalam belajar, seperti sering berbicara dengan temannya ketika pelajaran berlangsung, dan tidak memperhatikan guru saat 
aktifitas belajar mengajar. Ketika siswa mengalami kejenuhan dalam belajar maka kemungkinan siswa cenderung tidak akan memperhatikan guru pada saat proses belajar mengajar, dan akan sulit menerima informasi yang diberikan, sehingga akan berdampak pada perkembangan sosialnya dan sering gagal dalam mengerjakan tugas-tugas atau tanggung jawabnya sebagai seorang peserta didik.

Berdasarkan latar belakang di atas maka peneliti tertarik mengadakan penelitian dengan judul "Pengaruh Bimbingan Belajar Terhadap Kejenuhan Dalam Belajar Pada Siswa Kelas XI di SMAN 1 Gerung Kabupaten Lombok Barat Tahun Pelajaran 2015/2016".

\section{Metode Penelitian}

Rancangan pada dasarnya merupakan keseluruhan proses pemikiran dan penentuan matang tentang hal-hal yang akan dilakukan, dapat pula dijadikan dasar penilaian baik oleh peneliti itu sendiri maupun orang lain terhadap kegiatan penelitian.

Dilihat dari jenis penelitian, maka penelitian ini tergolong penelitian kuantitatif (penelitian statistik), dalam buku statistik untuk penelitian dijelaskan jenis penelitian kuantitatif yang diangkakan/scoring.

Berdasarkan metode pendekatan atau jenis penelitian, maka penelitian dapat membuat rancangan penelitian.Manfaat dari rancangan penelitian adalah untuk menggambarkan skema penelitian. Penelitian ini akan menggambarkan secara sistematis, akurat, actual tentang fakta yang akan diselidiki yaitu: Pengaruh bimbingan belajar terhadap kejenuhan dalam belajar. Menurut Sugiyono $(2014,39)$ ada 2 macam variabel penelitian yaitu:

\section{Variabel Independen (bebas)}

Variabel bebas merupakan variabel yang mempengaruhi atau yang menjadi sebab perubahanya atau timbulnya variabel dependen (terikat). Dalam penelitian ini yang menjadi variabel independen (bebas) adalah bimbingan belajar. 
el-HiKMAH, Vol. 12, No. 1, Juni 2018

\section{Variabel Dependen (terikat)}

Variabel terikat merupakan variabel yang dipengaruhi atau yang menjadi akibat, karena adanya variabel bebas.Dalam penelitian ini yang menjadi variabel terikat adalah kejenuhan dalam belajar. Dimana variabel $\mathrm{X}$ (bebas) memunculkan gejala bisa mempengaruhi variabel $Y$ (terikat).

Penelitian ini menggunakan desain penelitian one group pre test dan post test design dimana dalam rancangan ini terdapat satu kelompok subyek yaitu kelompok eksperimen sebagai kelompok yang diberikan perlakuan. Pertama-tama dilakukan pengukuran terhadap kelompok eksperimen, lalu dikenakan perlakuan bimbingan belajar dalam jangka waktu tertentu, kemudian dilakukan pengukuran untuk kedua kalinya dengan tujuan untuk mengetahui perbedaan hasil pre test sebelum diberikan perlakuan dengan post test setelah diberikan perlakuan. Untuk lebih jelsanya rancangan tersebut dapat digambarkan sebagai berikut:

\section{Gambar 1}

One Group pretest-post-test design

Gambar 01 Desain One Group Pretes Posttest Design

\section{$\mathrm{O}_{1} \times \mathrm{O}_{2}$}

Keterangan:

$\mathrm{O}_{1} \quad$ : Pre-test (sebelum perlakuan pada subyek eksperimen)

$\mathrm{X}$ : Perlakuan atau Treatment (Bimbingan Belajar)

$\mathrm{O}_{2} \quad$ : Post-test (Setelah perlakuan pada subyek eksperimen)

Tabel 1

Data Tentang Jumlah Siswa Kelas XI IPS diSMAN 1 Gerung Kabupaten Lombok Barat Tahun Pelajaran 2015/2016

\begin{tabular}{cccc}
\hline No & Kelas & Laki-laki & Perempuan \\
\hline 1 & XI.IPS. 1 & 19 & 17 \\
2 & XI. IPS. 2 & 20 & 17 \\
3 & XI. IPS. 3 & 20 & 16 \\
4 & XI. IPS 4 & 20 & 15 \\
& Jumlah Siswa & & $\mathbf{1 4 4}$ \\
\hline
\end{tabular}


Berdasarkan tabel di atas adapun jumlah Siswa Kelas XI IPS di SMAN 1 Gerung Kabupaten Lombok Barat Tahun Pelajaran 2015/2016 sebanyak 144 siswa yang menjadi populasi dalam penelitian ini.

Sedangkan Sampel adalah bagian dari jumlah dan karakteristik yang dimiliki oleh populasi. Bila populasi besar, dan peneliti tidak mungkin mempelajari semua yang ada pada populasi, misalnya keterbatasan dana, tenaga, dan waktu, maka peneliti dapat menggunakan sampel yang diambil dari populasi tersebut (Sugiyono 2014, 65).

Sehubungan dengan penelitian ini tehnik sampling yang digunakan adalah (purposive Sampling) atau pengambilan sampel secara acak berdasarkan pada pertimbangan atau tujuan tertentu. Dengan menggunakan purposive sampling untuk mendapatkan siswa yang memiliki kejenuhan dalam belajar. Disamping itu menurut pendapat Arikunto “jika populasi kurang dari 100, dianjurkan agar semuanya dijadikan sampel. Namun jika populasi lebih dari 100, maka dapat diambil 10-15\%, 20-25\% atau lebih tergantung kemampuan peneliti (Arikunto 2006, 134).

Berdasarkan hasil observasi dan wawancara dengan kepala sekolah dan guru BK, maka guru BK merekomendasikan 15 siswa kelas XI IPS yang mengalami kejenuhan dalam belajar. Dan akan mendapat perlakuan (treatment) bimbingan belajar.

Instrumen Instrumen adalah alat pada waktu penelitian yang menggunakan suatu metode" (Arikunto 2006, 134). Dalam penelitian ini instrumen yang digunakan adalah angket, metode dokumentasi (metode pelengkap), observasi dan wawancara. Tehnik analisis data dalam penelitian ini menggunkan rumus t-test. 
el-HiKMAH, Vol. 12, No. 1, Juni 2018

\section{Hasil dan Pembahasan}

\section{Tabel 2}

Jadwal Pelaksanaan Penelitian Sebelum dan Sesudah Memberikan

Bimbingan Belajar terhadap Kejenuhan dalam Belajar pada Siswa Kelas XI

IPS di SMAN 1 Gerung Kabupaten Lombok Barat

Tahun Pelajaran 2015/2016.

\begin{tabular}{|c|c|c|c|c|}
\hline No & Hari/ Tgl & Ruang & Kegiatan & Materi \\
\hline 1 & $\begin{array}{l}\text { Kamis, } 03 \\
\text { Maret } 2016\end{array}$ & Ruang TU & $\begin{array}{l}\text { Mengantar surat } \\
\text { izin dari Bapeda ke } \\
\text { sekolah }\end{array}$ & \\
\hline 2 & $\begin{array}{l}\text { Jum'at, } 04 \\
\text { Maret } 2016\end{array}$ & Ruang Kelas & $\begin{array}{l}\text { Perkenalan, kepada } \\
\text { siswa maksud dan } \\
\text { tujuan ke sekolah }\end{array}$ & $\begin{array}{l}\text { Penyebaranangket (pre- } \\
\text { test) kepada siswa }\end{array}$ \\
\hline 3 & $\begin{array}{l}\text { Senin, } 06 \\
\text { Maret } 2016\end{array}$ & Ruang Kelas & $\begin{array}{l}\text { Memberikan materi } \\
\text { Bimbingan Belajar }\end{array}$ & $\begin{array}{l}\text { a. Mengatasikelesuan } \\
\text { dalam belajar } \\
\text { b. Mengerjakan tugas- } \\
\text { tugas yang diberikan }\end{array}$ \\
\hline 4 & $\begin{array}{l}\text { Selasa, } 08 \\
\text { Agustus } \\
2016\end{array}$ & Ruang kelas & $\begin{array}{l}\text { Memberikan materi } \\
\text { Bimbingan Belajar }\end{array}$ & $\begin{array}{l}\text { a. Meningkatkan } \\
\text { konsentrasi belajar } \\
\text { b. Guru yang } \\
\text { menyenangkan }\end{array}$ \\
\hline 5 & $\begin{array}{l}\text { Rabu, } 09 \\
\text { Maret } 2016\end{array}$ & Ruang Kelas & $\begin{array}{l}\text { Memberikan materi } \\
\text { Bimbingan Belajar }\end{array}$ & $\begin{array}{l}\text { Meningkatkan gairah } \\
\text { dalam belajar }\end{array}$ \\
\hline 6 & $\begin{array}{l}\text { Kamis, } 10 \\
\text { Maret } 2016\end{array}$ & Ruang Kelas & & $\begin{array}{l}\text { Penyebaran angket } \\
\text { (Post-Test) kepada siswa }\end{array}$ \\
\hline
\end{tabular}

Dari tabel kegiatan tersebut, jelas bahwa sebelum perlakuan dilaksanakan, terlebih dahulu menyebarkan angket Kejenuhan dalam belajar kepada seluruh subyek, karena dalam penelitian ini menggunakan One group pre-test post test design. Hal ini dimaksudkan untuk mengetahui akibat dari perlakuan yang akan diberikan yaitu dengan membandingkan skor angket sebelum pelaksanaan layanan bimbingan belajar dengan skor angket setelah pelaksanaan bimbingan belajar. 
Tabel 3

Nilai Hasil Penghitungan Angket Pre-test dan Post-test Sikap Empati Pada Siswa Kelas XI IPS DI SMAN 1 Gerung Kabupaten Lonbok Barat Tahun Pelajaran 2015/2016.

\begin{tabular}{cccc}
\hline No & Kode Siswa & Pre-test & Post-test \\
\hline 1 & I N S & 62 & 70 \\
2 & N A H & 63 & 68 \\
3 & LL & 69 & 73 \\
4 & N S & 58 & 65 \\
5 & S R & 65 & 72 \\
6 & R R S & 52 & 63 \\
7 & R O & 66 & 71 \\
8 & R H & 53 & 69 \\
9 & I B & 60 & 66 \\
10 & L A & 67 & 72 \\
11 & H F & 54 & 62 \\
12 & D M & 42 & 59 \\
13 & R D S & 53 & 61 \\
14 & B M S & 58 & 65 \\
15 & R D U & 50 & 57 \\
& $\mathbf{N = 1 5}$ & $\mathbf{8 7 2}$ & $\mathbf{9 9 3}$ \\
\hline
\end{tabular}

Tabel 4

Tabel Kerja Untuk Menghitung Nilai $t$ dengan Menggunakan Rumus Analisis t-test

\begin{tabular}{|c|c|c|c|c|c|c|}
\hline No & $\begin{array}{l}\text { Kode } \\
\text { Siswa }\end{array}$ & $\begin{array}{c}\text { Pre- } \\
\text { test }\end{array}$ & $\begin{array}{c}\text { Post- } \\
\text { test }\end{array}$ & $\begin{array}{l}\text { Gaind (d) } \\
\text { (Post-Pre) }\end{array}$ & $\begin{array}{c}X d \\
\text { (d-Md) }\end{array}$ & $\sum x^{2} d$ \\
\hline 1 & I N S & 62 & 70 & 8 & 0,067 & 0,004489 \\
\hline 2 & $\mathrm{NAH}$ & 63 & 68 & 5 & 3,067 & 9,406489 \\
\hline 3 & L L & 69 & 73 & 4 & 4,067 & 16,540489 \\
\hline 4 & $\mathrm{~N} \mathrm{~S}$ & 58 & 65 & 7 & 1,067 & 1,138489 \\
\hline 5 & S R & 65 & 72 & 7 & 1,067 & 1,138489 \\
\hline 6 & R R S & 52 & 63 & 11 & $-2,933$ & 8,602489 \\
\hline 7 & $\mathrm{RO}$ & 66 & 71 & 5 & 3,067 & 9,406489 \\
\hline 8 & R H & 53 & 69 & 16 & $-7,933$ & 62,932489 \\
\hline 9 & I B & 60 & 66 & 6 & 2,067 & 4,272489 \\
\hline 10 & L A & 67 & 72 & 5 & 3,067 & 9,406489 \\
\hline 11 & $\mathrm{HF}$ & 54 & 62 & 8 & 0,067 & 0,004489 \\
\hline 12 & $\mathrm{D} M$ & 42 & 59 & 17 & $-8,933$ & 79,798489 \\
\hline 13 & R D S & 53 & 61 & 8 & 0,067 & 0,004489 \\
\hline 14 & B M S & 58 & 65 & 7 & 1,067 & 1,138489 \\
\hline 15 & R D U & 50 & 57 & 7 & 1,067 & 1,138489 \\
\hline \multicolumn{2}{|c|}{$\mathrm{N}=15$} & 872 & 993 & 121 & 0,005 & 204,933335 \\
\hline
\end{tabular}




\section{Pembahasan}

Menurut Winkel, "Bimbingan belajar adalah suatu bantuan dari pembimbing kepada individu (siswa) dalam hal menemukan cara belajar yang tepat, dalam memilih program studi yang sesuai dan dalam mengatasi kesukaran-kesukaran yang timbul berkaitan dengan tuntutan-tuntutn belajar di institusi pendidikan" (Tohirin 2014, 127). Sedangkan menurut Surya, "Bimbingan belajar merupakan jenis bimbingan yang membantu para siswa dalam menghadapi dan memecahkan masalah-masalah pendidikan" (Tohirin 2014, 127).

Berdasarkan pendapat ahli di atas dapat disimpulkan bahwa bimingan belajar adalah suatu bantuan dari pembimbing kepada terbimbing siswa dalam menghadapi atau memecahkan masalahmasalah belajar dalam (arti sempit) dan pendidikan dalam (arti luas).

Singgih dan Yulia mengatakan bahwa: Bimbingan belajar bertujuan memecahkan persoalan berhubungan dengan masalah belajar anak sekolah di sekolah dan di luar sekolah dalam hal: 1) Mencarikan cara belajar yang effisien bagi seorang anak atau sekelompok anak, 2) Menunjukkan cara-cara mempelajari sesuatu dan menggunakan buku pelajaran, 3) Memberikan syarat dan petunjuk bagaimana memanfaatkan perpustakaan, 4) Membuat tugas sekolah dan mempersiapkan diri untuk ulangan tiba-tiba atau ulangan biasa dan ujian, 5) Memilih suatu pelajaran (mayor atau minor) sesuai dengan minat, bakat, kepandaian, angan-angan dan kondisi kesehatan/fisiknya, 6) Menunjukkan cara-cara menghadapi kesulitan dalam mata pelajaran tertentu, 7) Menentukan pembagian waktu dan perencanaan jadwal belajar, 8) Memilihh pelajaran tambahan, baik yang berhubungan dengan pelajaran di sekolah maupun untuk pengembangan bakat anak sendiri (Gunarsa dan Gunarsa 2012, 36).

Berdasarkan pendapat ahli di atas dapat disimpulkan bahwa tujuan dari layanan bimbingan belajar adalah membantu individu (siswa) agar mencapai perkembangan yang optimal, mampu 
menghadapi dan memecahkan masalah-masalah belajar baik di sekolah maupun di luar sekolah.

Menurut Sunaryo Kuswana, "Bosan merupakan suatu peristiwa yang sudah tidak disukai lagi karena terlalu banyak dan sering menerima informasi, sehingga seseorang akan merasa jemu. Adapun jenuh merupakan suatu keadaan bosan sebagai akibat dari banyaknya informasi yang nyaris tidak tertampung dalam memori". Kejenuhan belajar dialami seseorang yang belajar pada rentang waktu tertentu dengan tidak memperoleh sesuatu hasil berupa pengetahuan atau keterampilan (Kuswana 2011, 257).

Berdasarkan pendapat ahli diatas, dapat disimpulkan bahwa kejenuhan dalam belajar ialah suatu keadaan bosan atau jenuh yang amat sangat sehingga menimbulkan rasa lesu tidak bersemangat karena terlalu banyak menerima atau memperoleh suatu informasi yang berupa pengetahuan atau keterampilan.

Yang dimaksud dengan kejenuhan dalam belajar dalam penelitian ini adalah suatu keadaan bosan/jenuh yang dialami siswa pada saat prose belajar mengajar berlangsung, yang disebabkan karena terlalu banyak menerima/memperoleh suatu informasi yang berupa pengetahuan atau keterampilan.

Afifuddin (2012: 194), menyatakan bahwa: Ciri-ciri anak yang mengalami kejenuhan dalam belajar adalah:

1. Tidak dapat mengikuti pelajaran seperti yang lain,

2. Sering terlambat atau tidak mau menyelesaikan tugas,

3. Menghindari tugs-tugas yang agak berat,

4. Ceroboh atau kurang teliti dalam banyak hal,

5. Acuh tak acuh atau masa bodoh,

6. Menampakkan semangat belajar yang rendah,

7. Tidak mampu berkonsentrasi, mudah berubah-berubah,

8. Perhatian terhadap suatu objek singkat,

9. Suka menyendiri, sulit menyesuaikan diri,

10. Murung

11. suka memberontak, agresif, dan meledak-ledak dalam merespon ketidakcocokan, hasil belajar rendah. 
Berdasarkan uraian di atas maka ciri -ciri kejenuhan dalam belajar adalah merasa bahwa pengetahuan dan kecakapan dalam proses belajar tidak ada kemajuan, sistem akalnya tidak dapat bekerja sebagai mana yang diharapkan dalam memproses informasi atau pengalaman, kehilangan motivasi dalam belajar.

Dalam penelitian ini, analisis data dilakukan dua kali yaitu sebelum dan sesudah diberikan bimbingan belajar, karena dalam penelitian ini menggunakan desain one group pre-test post-test design, dimana menggunakan satu kelompok eksperimen.

Berdasarkan analisis data yang di gunakan adalah metode statistic dengan menggunakan rumust-tes ( $t$ bitung8,166 $>t$ tablel 2,145) dengan taraf signifikan 5\% yang menolak hipotesis nihil (Ho), berarti hipotesis alternatif ( $\mathrm{Ha}$ ) yang berbunyi: Ada Pengaruh Bimbingan Belajar Terhadap Kejenuhan Dalam Belajar Pada Siswa Kelas XI IPS di SMAN 1 Gerung Kabupaten Lombok Barat TahunPelajaran 2015/2016 diterima.

Pemberian layanan bimbingan belajar sangat berguna bagi siswa untuk menghilangkan kejenuhan dalam belajar, setelah pemberian bimbingan belajar siswa-siswi tersebut mampu menghilangkan kejenuhan mereka di saat proses belajar mengajar berlangsung, dan lebih bersemangat lagi untuk mengikuti pelajaran di sekolah.

Pelaksanaan bimbingan belajar juga ditujukan kepada pihak yang terkait terutama guru $\mathrm{BK}$, hendaknya melaksanakan bimbingan belajardan dilaksanakan secara terprogram, karena terbukti bahwa dengan bimbingan belajar mampu memberikan pemahman yang lebih mendalam dan mengenak pada diri siswa dibandingkan dengan bimbingan yang lain, selain itu pula kepada kepala sekolah, dan guru mata pelajaran hendaknya selalu menjalin kerjasama yang baik dengan orang tua/wali murid dan terus mendorong serta mengarahkan anak-anaknya dengan sebaiksebaiknya sehingga para siswa mampu menghilangkan kejenuhan dalam belajar dan lebih bersemangat dalam belajar.

Layanan bimbingan belajar bertujuan untuk membantu individu agar mampu menghilangkan kejenuhan dalam belajar siswa, supaya siswa tersebut sadar bahwa kejenuhan dalam belajar akan 
mengahambat dirinya dalam melakukan hal-hal yang menguntungkannya seperti nanti di waktu melanjutkan pendidikan ke jenjang yang lebih tinggi.

Dengan demikian, bahwapelaksanaanbimbingan belajar mempunyai peran yang positif dalam mengurangi kejenuhan dalam belajar pada siswa kelas XI IPS di SMAN 1 Gerung Kabupaten Lombok Barat Tahun Pelajaran 2015/2016. Dengan kata lain semakin baik pelaksanaan bimbingan belajar di sekolah, maka kejenuhan dalam belajar pada siswa akan menjadi semakin berkurang.

\section{Catatan Akhir}

Berdasarkan hasil analisis data dan pembahasan BAB IV maka dapat disimpulkan bahwa: Ada Pengaruh Bimbingan Belajar Terhadap Kejenuhan Dalam Belajar Pada Siswa Kelas XI IPS di SMAN 1 Gerung Kabupaten Lombok Barat Tahun Pelajaran 2015/2016. Hal ini dapat dilihat dari hasil penelitian yaitu: nilai $t$ hitung sebesar $=8,166$ dan nilai $t$ pada tabel $=2,145$ ini menunjukkan bahwa $(8,166>2,145)$, hipotesis alternatif $(\mathrm{Ha})$ diterima sedangkan hipotesis nihil (Ho) ditolak. Yang berarti hasil penelitian ini adalah "signifikan" dengan demikian dapat di tarik kesimpulan bahwa ada Pengaruh Bimbingan Belajar Terhadap Kejenuhan Dalam Belajar Pada Siswa Kelas XI IPS di SMAN 1 Gerung Kabupaten Lombok Barat Tahun Pelajaran 2015/2016.

Dari kesimpulan yang diperoleh dalam penelitian ini, maka dapat diajukan saran sebagai berikut:

1. Bagi kepala sekolah, supaya lebih memperhatikan fasilitas yang dibutuhkan oleh guru bimbingan dan konseling demi terlaksananya layanan bimbingan belajar bagi siswa siswi di SMAN 1 Gerung.

2. Kepada guru BK, hendaknya pelaksanaan layanan bimbingan belajar di lakukan secara intensif dan terprogram, karena terbukti bahwa bimbingan belajar akan membantu siswa dalam meningkatkan motivasi belajar. 
3. Kepada siswa, hendaknya betul-betul memanfaatkan layanan bimbingan belajar yang ada di sekolah, sehingga memiliki semangat belajar yang tinggi.

4. Kepada orang tua/wali murid, hendaknya terus mendorong dan ikut serta dalam meningkatkan motivasi belajarsiswa.

5. Bagi para peneliti selanjutnya diharapkan hasil penelitian ini dapat dijadikan acuan untuk mengungkap aspek-aspek yang lebih luas yang belum terungkap dalam penelitian ini.

\section{Daftar Pustaka}

Afifuddin. 2012. Bimbingan dan Penyuluhan. Bandung: Pustaka Setia. Ali dan Asrori. 2010. Psikologi Remaja Perkembangan Peserta Didik. Jakarta: PT Bumi Aksara Jakarta.

Arikunto, Suharsimi. 2006. Prosedur Penelitian Pendekatan Suatu Praktik. Jakarta: Rineka Cipta.

Arifin, 2011. Penelitian Pendidikan. Bandung: PT Rosda Karya.

Gunarsa, Singgih D., dan Yulia Singgih D. Gunarsa. 2012. Psikologi Untuk Membimbing. Jakarta: BPK Gunung Mulia.

Hartono \& Soedarmadji. 2012. Psokologi Konseling. Jakarta: Kencana Prenada Media Group.

Kuswana, W. Sunaryo. 2011. Taksonomi Berfikir. Bandung: Remaja Rosda Karya.

Mardalis. 2004. Metodologi Risearch Sosial. Rineka Cipta : Jakarta.

Narbuko dan Achmadi, 2007. Metodologi Penelitian Pendidikan. Jakarta: PT Rineka Cipta.

Sugiyono. 2014. Metode Penelitian Kuantitatif, Kualitatif, dan R \& D. Bandung: Alfabeta.

Tohirin. 2014. Bimbinan dan Konseling di sekolah dan Madrasah. Jakarta: Raja Grafindo Persada. 